\title{
Hysteroscopic removal of uterine cysts in mares I - Hysteroscopy and surgical procedures
}

\author{
Claus Peter Bartmann', Melanie Köllmann', Viola Schiemann', Birgit Stief², Heinz-Adolf Schoon² and Erich Klug ${ }^{7}$
}

Clinic for horses, University of Veterinary Medicine Hannover, Germany; Foundation' ${ }^{1}$ and Institute of Pathology, Faculty of Veterinary Medicine University of Leipzig

\begin{abstract}
Summary
222 barren mares of different breeds underwent operative hysteroscopy for the treatment of uterine cysts during an eleven year period. Hysteroscopy was performed under sedation. Mares were in di- or anoestrus. Uterine distension was standardized with an intrauterine pressure between 20-30 mm Hg. Thermical preparation was achieved with high-frequency electrosurgery using micro instruments through the working channel of the endoscope. All visible cysts were resected with an electrosurgical loop. The loop was tightened around the base of the cyst and the cyst pulled towards the uterine lumen before resection. Small cysts which could not be fixed with the loop were coagulated. With the standard procedures, operative hysteroscopy could be completed with resection of all visible cysts in all the mares without complications. Therefore, the technique described here proved to be safe and efficient in a large number of treated mares. Compared to other preparation techniques, risk of recurrence is minimized, trauma of the tissue is only superficial and the wound healing is uncomplicated. The results of patho-histological examination of endometrial biopsies and of clinical follow-up with high rates of treated mares conceiving and foaling are presented in the second part of this study by Köllmann et al. (2008).
\end{abstract}

Keywords: mare, endometrial cysts, operative hysteroscopy, intrauterine pressure, intrauterine wound healing, reproduction

\section{Hysteroskopische Entfernung von Gebärmutterzysten beim Pferd I - Hysteroskopie und chirurgische Technik}

Innerhalb eines Zeitraumes von elf Jahren wurden 222 Stuten verschiedener Pferderassen mit einer Güstzeit von mindestens einem Jahr zur Behandlung von Uteruszysten einer operativen Hysteroskopie unterzogen. Der hysteroskopische Eingriff erfolgte an der sedierten Stute immer im Inter- oder Anöstrus mit einem standardisierten intrauterinen Arbeitsdruck von 20-30 mm Hg. Zur Anwendung kam als thermisches Präparationsverfahren die Hochfrequenz-Elektrochirurgie mit durch den Arbeitskanal eingesetzten flexiblen Instrumenten. Soweit möglich wurden alle erkennbaren Zysten nacheinander mit einer diathermischen Schlinge an ihrer Basis erfasst, zentripedal abgehoben und hochfrequenzchirurgisch abgesetzt. Nicht greifbare Zysten wurden mit einem hochfrequenzchirurgischen Instrument punktförmig koaguliert. Mit dieser Vorgehensweise konnte die operative Hysteroskopie bei allen Stuten mit der Entfernung aller erkennbaren Zysten komplikationsfrei abgeschlossen werden. Die beschriebene Operationstechnik hat sich bei einer großen Anzahl von Stuten als sicher und effektiv erwiesen. Gleichzeitig ist im Vergleich zu anderen Präparationstechniken bei minimiertem Rezidivrisiko eine nur geringe und oberflächliche Gewebetraumatisierung und unkomplizierte Wundheilung möglich. Die hohe Konzeptions- und Abfohlrate von behandelten Stuten sowie die Ergebnisse der patho-histologischen Beurteilung von Endometriumbiopsien der Stuten wird im zweiten Teil der Arbeit bei Köllmann et al. (2008) dargestellt.

Schlüsselwörter: Stute, Endometriumzysten, operative Hysteroskopie, intrauteriner Druck, HF-Elektrochirurgie, intrauterine Wundheilung

\section{Introduction}

Hysteroscopy in the mare is a routinely employed tool for advanced diagnostics and minimally invasive endouterine surgery. Endoscopic examination of the uterine cavity provides visualisation of localized alterations like non-generalised inflammations, endometrial cysts, scars and adhesions, which can be difficult to find during gynaecological basic examination. For this the use of flexible endoscopes has proved to be the most suitable (Merkt et al. 1991, Bracher et al. 1992).

But not only for diagnostics also for minimally invasive surgical treatment of intrauterine diseases operative hysteroscopy turned out to be a considerable technique. Besides the use of rigid instruments inserted parallel to the endoscope, it is also possible to pass flexible devices through the working channel of the scope. As well as in human gynaecology, thermical preparation techniques like high frequency electro surgery and laser technology are essential tools for an effective endouterine surgery (Brook and Frankel 1987, Allen et al. 1997, Bartmann et al. 1997, Ley et al. 2002).
Uterine cysts, intrauterine adhesions and uterine tumours may be a reason for infertility in the horse due to uterine occlusion leading to reduction of the mobility of the early conceptus and disturbance of the mechanical clearance.

Endometrial cysts as lymph cysts, lymphangiectasia and phlebectasia are symptoms of endometrial perfusion disorders associated with related angiopathies. Due to obstruction of the uterine lumen endometrial cysts can hamper semen transport to the fallopian tubes. A reduction of total area of microcotyledonary contact may result in lower fertility (Leidl et al. 1987, Allen et al. 1997) and the intrauterine migration of the early conceptus can be handicapped as well which leads to a lack of hormonal signals necessary for preservation of pregnancy. Therefore fertility can be eminently increased by resection or coagulation of these cysts (Brook and Frankel 1987, Allen et al. 1997, Bartmann et al. 1997). A pregnancy rate of $66 \%$ could be achieved in barren mares subsequent to operative hysteroscopy in the following season (Bartmann et al. 1997). 
A distension of the uterine cavity and an establishment of a continuous intrauterine pressure are basic requirements for complete visualisation of intrauterine structures and safe and efficient surgical procedures. Superelevated pressure and resorption of distension media may result in fatal complications (Robbins and Sato 1991, Vacca et al. 1997, Hucke 2000).

Nevertheless, different techniques for the minimal invasive treatment of uterine cysts have been described without standard techniques for a large number of mares.

The objectives of this study were to transmit the results of basic research on intrauterine wound healing (Bartmann et al. 2003) and uterine distension as a basic requirement for hysteroscopy in mares (Bartmann and Schiemann 2003) on a large number of equine patients with a follow-up.

\section{Material and method}

Over an eleven year period 222 mares of different breed and age underwent operative hysteroscopy with standard distension and surgical procedures for a minimal invasive therapy of uterine cysts.

Only reproductively sound but barren mares with a history of in- or subfertility were included in this investigation. Most mares were treated as coming in patients and went home the same day.

Initially a complete clinical and ultrasonographic examination was required. Mares with clinical or microbiological signs of genital disease or inflammation and infection were treated medically prior to surgery but were excluded from this investigation. Pregnancy was excluded. All diagnostic and surgical procedures were performed in an- or interoestrus mares.

For surgical procedures, the mares were restrained in a stock and tranquilised with an intravenous injection of $0.4 \mathrm{mg} / \mathrm{kg}$ xylazine (Xylapan ${ }^{\circledR}$, Vetoquinol, Ravensburg, Germany) and $0.075 \mathrm{mg} / \mathrm{kg}$ levomethadon (Polamivet ${ }^{\circledR}$, Intervet, Munich, Germany). The tail was secured with a bandage. Following antiseptic preparation of the outer genital, a flexible video endoscope of $200 \mathrm{~cm}$ in length (SIF 100, Olympus, Hamburg, Germany) was passed under digital control through the cervix into the uterine body.

An average intrauterine pressure of $25 \pm 5 \mathrm{mmHg}$ as has been described by Bartmann and Schiemann (2003) was adjusted for distension of the cavum uteri by insufflation of filtered atmospheric air using the endoscopic pump (cold light source: CLV-U20, Olympus, Hamburg, Germany). A complete exploration of the uterine cavity was performed visualizing both uterine horns including the junction to the fallopian tubes, the uterine body and the internal cervical orifice by making a "U-turn". Colour and degree of moisture and oedema of the endometrium, free fluid, adhesions and visible cysts were documented. Cysts were classified into categories 1 to 3 according to Bartmann et al. (1997).

Following diagnostic procedures, all detectable cysts were removed transendoscopically using high frequency electrosurgery (Erbotom T400B, Fa. Erbe Elektromedizin).
For resection of endometrial cysts an electrosurgical loop was placed via the working channel of the endoscope over the cyst and then tightened around its basis (fig. 1 a-c). The fixed cyst was slightly pulled towards the uterine lumen and diathermic energy was applied until the cyst was resected. If this basis was found to be too wide to place the loop the cysts were coagulated with superficial administration of a cutting needle (fig. 2 a-b) with the technique described by Bartmann et al. (2003). During the hysteroscopic session all discernable luminal cysts were removed. In case of mul-
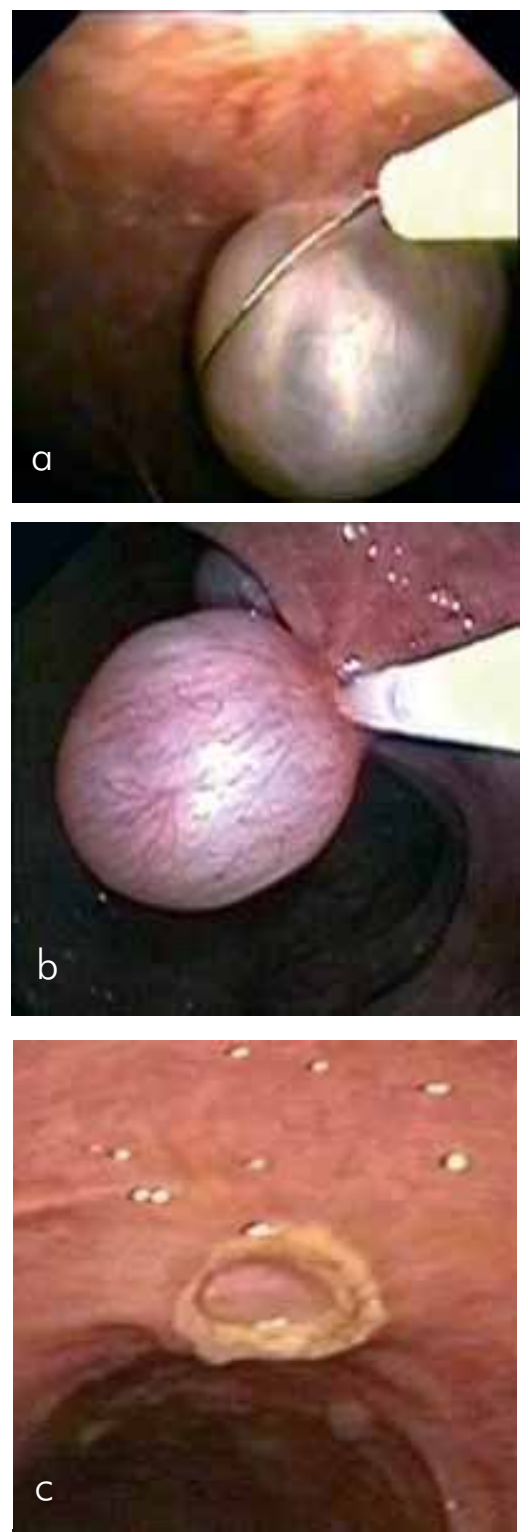

Abb 1a-c Resektion einer Zyste mit der elektrochirurgischen Schlinge (Polypektomieschlinge). Elektrochirurgische Schlinge wird über Zyste gelegt (a) und an der Zystenbasis zusammengezogen und fixiert (b). Koagulierter Amputationsstumpf nach hochfrequenzchirurgischer Zystenentnahme. Gute Hämostase (c).

Resection of a cyst with an electrosurgical loop. Snare looped over the cyst (a) and tightened around the basis. Blanched amputation stump with excellent haemostasis (c).

tiple cysts, uterine lavage with saline was performed finally to remove the dissected tissue out of the uterus. Endometrial biopsies of each mare were taken with Ferris biopsy forceps. 
After completion of the diagnostic and surgical procedures, the uterus was evacuated and treated antiseptically with instillation of $100 \mathrm{ml}$ of a mild $1 \%$ povidone iodine solution (Vetisept, Albrecht, Aulendorf or Braunol, B. Braun, Melsungen, Germany). Oestrus was induced by application of 250mg cloprostenol (Estrumate, Essex Tierarznei, Munich, Germany).

\section{Results}

Diagnostic and minimal invasive surgical procedures could be completed in all the 222 mares. Details on age, breed, patho-histological results and further breeding results of these mares are given by Köllmann et al. (2008).

Sedation with xylazine and levomethadone was judged to be adequate for a safe surgery. Transcervical passage of the endoscope was possible with a light manipulation. On the other hand, cervical tone allowed insufflation and administration of an intrauterine pressure between 20 and $30 \mathrm{~mm}$ $\mathrm{Hg}$. This pressure was excellent for visualisation of all intrauterine structures and was tolerated by the mares.

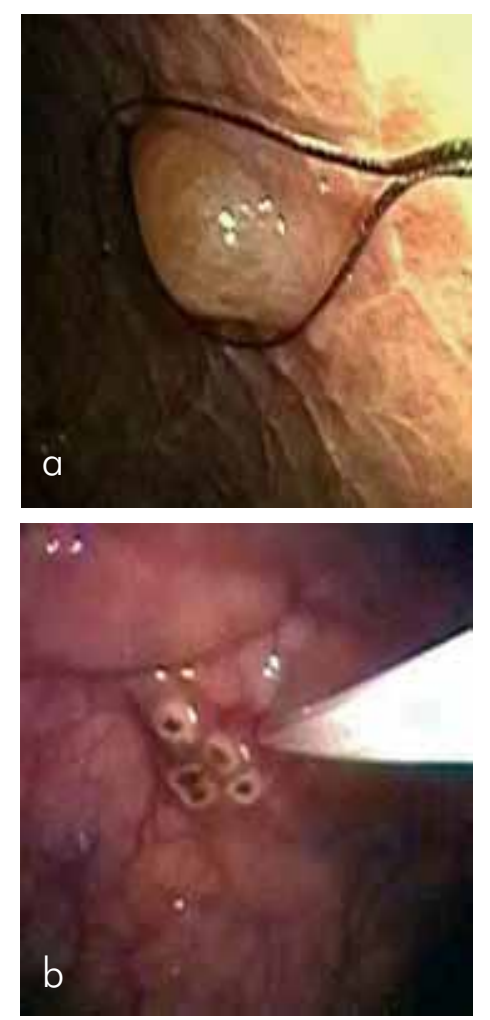

Abb 2 a-b Koagulation einer kleinen Zyste vom Typ III. Schlinge kann nicht an Zystenbasis zusammengezogen werden (a). Punktförmige Koagulation der Zyste (b).

Coagulation of a smaller cyst type II. Loop can not be tightened around the cyst. Punctual coagulation (b).

Maximum diameter of intrauterine cysts was $5.8 \mathrm{~cm}$ and the largest number of cysts found per mare was 24. Cysts of type 1 were completely resected with an electrosurgical loop. Cysts of type 2 and 3 were coagulated. Resection of cysts with an electrosurgical loop resulted in a small and superficial craterlike endometrial lesion with excellent haemostasis. Remo- val of dislodged pieces of tissue or cysts was accomplished with a uterus lavage.

No signs of perforation or severe hemorrhage were registered during any of the surgeries. Operative hysteroscopies with resection of all detected cysts could be terminated in between 45 minutes.

\section{Discussion}

Operative hysteroscopy in the mare is a reliable technique for the reduction of intrauterine masses or occlusions, mainly caused by uterine cysts. Effective intrauterine preparation can only be achieved by thermal preparation techniques (Brook and Frankel 1987, Allen et al. 1997, Bartmann et al. 1997). However, technically more difficult surgical techniques increase the risk of potential complications like uterine perforation, thermal injury of other intraabdominal organs and loss of functional tissue (Baggish et al. 1992, Wallwiener et al. 1992, Beck and Bender 1996, Hucke 2000).

Basic research of the effects of thermal preparation on reproductive organs of the horse has been limited. Blikslager et al. (1993) evaluated the effect of $\mathrm{Nd}$ :YAG laser irradiation on equine endometrium but only in vitro with refrigerated uteri. Bartmann et al. (2003) compared the effects of different preparation techniques on the equine endometrium clinically, by hysteroscopy and patho-histologically following hysterectomy. To determine the effect of $\mathrm{Nd}$ :YAG laser surgery on the uterine wall compared with electrosurgery, standard lesions were obtained by transendoscopic monopolar electrosurgery and laser surgery in healthy mares on consecutive days. The different energy forms caused tissue alterations of comparable quality but differing in degree. Non contact laser irradiation initiated maximal amount of fibrinous exudate. Lesions created with a loop electrode were superficial only and did only affect the endometrium. Preparation with an electrosurgical cutting blade or a laser bare fibre resulted in craterlike lesions lined by carbonisation and did involve deeper layers of the myometrium. The lesions caused by non contact laser irradiation affected all layers of the uterine wall. The depth of thermal injury and coagulative necrosis, inflammatory reactions and scar formation was greater in lesions created by laser application compared with those set with a loop electrode at power densities comparable to those usually achieved at hysteroscopic surgery (Bartmann et al. 2003).

With the electrosurgical resection, the entire cyst is removed which reduces the recurrence compared to the techniques of cyst incision or puncture (Wilson 1985, Merkt et al. 1991, Bracher et al. 1992). Laser ablation of cysts (Blikslager et al. 1993, Allen et al. 1997) was judged to be effective for the treatment of cysts but may result in thermal necrosis in deep tissue layers, delayed perforation oft the uterus and extended scar formation (Wamsteker 1992, Bartmann et al. 2003).

The results suggest that an electrosurgical loop designed for operative hysteroscopy may be a reliable tool for diathermic resection of pathological endometrial structures like uterine cysts characterized by minimal thermal injuries and a short period of reconvalescence. 
The choice of the correct stage of cycle is of considerable importance in order to establish and maintain uterine distension. It is advantageous to perform a hysteroscopy during dioestrus when the cervical seal is tight, because efflux of distension media is minimal at this time and an efficient insufflation is possible (Bracher et al. 1992, Bartmann et al. 1997, Schiemann et al. 2001, Bartmann and Schiemann 2003). Furthermore due to the lack of estrous endometrial edema the visual assessment of pathological findings is improved. The passage of the endoscope through the more or less tightly closed cervix during diestrus is unproblematic. Anoestrus is also a stage in the cycle suitable for establishing adequate visualization and good working conditions.

A safe and efficient hysteroscopy could be performed with a mean pressure of around $20 \mathrm{~mm} \mathrm{Hg}$ and an upper pressure limit of $30 \mathrm{~mm} \mathrm{Hg}$.

In the hand of a skilled team operative hysteroscopy is a profitable tool for equine fertility surgery with a comparatively low risk for complications. Especially for minimally invasive treatment of endometrial cysts and intrauterine adhesiolysis (Bracher et al. 1994, Bartmann et al. 2000) this procedure in the standing horse has proved to be effective and secure. Even prophylactic removal of detected cysts can be recommended. The choice of an adequate minimal invasive preparation and resection technique in addition to standard distension and diagnostic procedures were judged to be of considerable value for uncomplicated and effective surgery in a large number of mares in this study.

\section{References}

Allen W. R., Bracher V., Mathias S., Turnbull C. and Gerstenberg C. (1997) Keyhole laser ablation of transluminal adhesions and endometrial cysts in the uteri of Thoroughbred mares. Pferdeheilkunde 13, 536

Baggish M. S., Barash F., Noel Y. and Brooks M. (1992) Comparison of thermal injury zones in loop electrical and laser cervical excisional conization. Am. J. Obstet. Gynecol. 163, 545-548

Bartmann C. P. and Schiemann V. (2003) Untersuchungen zur Entwicklung eines intrauterinen Distensionsdrucks für die Hysteroskopie beim Pferd. Dłsch. Tierärzłl. Wschr. 110, 43-48

Bartmann C. P., Schöning A., Brickwedel I., Ohnesorge B. and Klug E. (1997) Hysteroskopie und minimal invasive endouterine Chirurgie bei der Stute. Pferdeheilkunde 13, 474-482

Bartmann C. P., Brickwedel I. and Klug E. (2000) Hysteroskopische hochfrequenzchirurgische Behandlung intrauteriner Adhäsionen beim Pferd. Tierärztl. Prax. 28 (G), 233-239

Bartmann C. P., Stief B. and Schoon H.-A. (2003) Thermische Verletzung und Wundheilung des Endometriums nach minimal invasiver transendoskopischer Anwendung von Nd:YAG-Laser- und Hochfrequenzchirurgie beim Pferd. Dłsch. Tierärztl. Wschr. 110, 271279
Beck L. and Bender H. G. (1996) Intra- und postoperative Komplikationen in der Gynäkologie und Geburtshilfe. Verlag Thieme, Stuttgart

Blikslager A. T., Tate L. P. and Weinstock E. (1993) Effects of neodymium: yttrium aluminium garnet laser irradiation on endometrium and on endometrial cysts in six mares. Vet. Surgery 22, 351-356

Bracher V., Stone R. and Allen W. R. (1992) Videoendoscopic evaluation of the mare's uterus: II. Findings in subfertile mares. Equine vet. J. 24, 279-284

Bracher V., Stone R. and Allen W. R. (1994) Transendoscopic $\mathrm{Nd}$ :YAG laser surgery for treatment of intrauterine adhesions in four mares. Equine Vet. Educ. 6, 22-26

Brook D. and Frankel K. (1987) Electrocoagulative removal of endometrial cysts in the mare. J. Equine Vet. Sci. 7, 77-81

Hucke J. (2000): Komplikationen der Hysteroskopie. In: Keckstein J. and Hucke J. (Hrsg.): Die endoskopischen Operationen in der Gynäkologie. Verlag Urban \& Fischer, München, Jena, 359-376

Köllmann M., Bartmann, C. P., Schiemann V., Klug E., Ellenberger C. and Schoon H.-A. (2008) Hysteroscopic removal of uterine cysts in mares. II. Follow-up and long term fertility analysis with regard to patho-histological findings. Pferdeheilkunde 24, in press

Leidl W., Kaspar B., Kähn B. and Kähn W. (1987) Endometriumzysten bei Stuten. Teil 2. Klinische Untersuchungen: Vorkommen und Bedeutung. Tierärztl. Praxis 15, 281-289

Ley W. B., Higbee R. and Holyoak G. R. (2002) Laser ablation of endometrial and lymphatic cysts. Clinical Techniques in Equine Practice 1, 28-31

Merkt H., Deegen E., Dieckmann M., Bader H., Gremmes S., Merkt J. C. and Werhahn H. (1991) Zysten in der Gebärmutterwand von Stuten sowie Behandlungsversuche unter hysteroskopischer Kontrolle. Pferdeheilkunde 7, 251-256

Robbins A. and Sato Y. (1991) Cardiovascular changes in response to uterine stimulation. J. Autonom. Nerv. System 33, 55-64

Schiemann V., Bartmann C. P. and Hoppen H.-O. (2001) Influence of the peripheral progesterone level on uterine distension during hysteroscopy in the horse. Pferdeheilkunde 17, 161-164

Vacca G., Battaglia A., Grossini E., Mary D.A.S.G., Molinari C. and Surico N. (1997) Reflex haemodynamic responses caused by distension of the uterus in anaesthetized pigs. J. Autonom. Nerv. System 63, 1-11

Wallwiener D., Rimbach S, Pollmann D. and Bastert G. (1992) Endoskopische Präparationstechniken. In: Endoscopic Surgery in Gynecology. Lueken R. P. and A. Gallinat, Ed. Demeter, Gräfelfing, 9-27

Wamsteker D. (1992) HF-Electrosurgery versus laser in hysteroscopy. In: Bastert G. and Wallwiener D. (Eds): Laser in Gynecology. Possibilities and Limitations. Springer, Berlin, Heidelberg, 211-214

Wilson G. L. (1985) Diagnostic and therapeutic hysteroscopy for endometrial cysts in mares. Vet med. Small Anim. Clin. 80, 59-62

PD Dr. Claus Peter Bartmann

Einsatz- und Ausbildungszentrum für Gebirgstragtierwesen 230

Nonner Str. 25

83435 Bad Reichenhall

cpbartmann@t-online.de 